\title{
THE ASSOCIATION BETWEEN FAST-FOOD CONSUMPTION AND PHYSICAL ACTIVITY WITH OVERWEIGHT OCCURRENCE AT SCHOOL AMONG 9-11- YEAR-OLD CHILDREN IN CAKUNG PAYANGAN BEKASI
}

\author{
Iin Fatmawati, Andreas Wisnu Pradhan, Firlia Ayu Arini \\ Department of Nutrition Faculty of Health Sciences University of Pembangunan Nasional Veteran Jakarta, \\ Street. Limo Raya, Depok, West Java, Indonesia.
}

\begin{abstract}
Overweight occurs because of excessive energy intake stored in the form of fat tissue. The national prevalence of overweight and obesity among children aged 5-12 years old was 10.8\% and 8.8\%, respectively. Several factors are responsible for increasing the prevalence of overweight, including food consumption and physical activity. The purpose of this study was to examine the association between fastfood consumption and physical activity with the overweight occurrence among school-aged children in Cakung Payangan, Bekasi. This is a cross-sectional study with a total of 80 students recruited through a simple random sampling method. There was a significant association between fast-food consumption and overweight ( $p=0.013$, CI 95\% = 1,420 - 10,977). Also, there was a significant association between physical activity and overweight $(p=0.027$, CI 95\% = 1,023-74,825). Frequent fast-food consumption and mild physical activity have a significant relationship with overweight occurrence among school-aged children.
\end{abstract}

Keywords: Physical activity, school-aged children, consumption of fast food, overweight.

\begin{abstract}
ABSTRAK
Gizi lebih terjadi karena asupan energi yang berlebih ke dalam tubuh, dan disimpan dalam bentuk jaringan lemak. Prevalensi nasional gizi lebih pada anak usia 5-12 tahun sebesar 10,8\% dan obesitas sebesar 8,8\%. peningkatan prevalensi gizi lebih disebabkan oleh banyak faktor, diantaranya adalah konsumsi makanan dan aktivitas fisik yang rendah. Penelitian ini bertujuan melihat hubungan konsumsi fast food dan aktivitas fisik dengan kejadian gizi lebih pada anak usia sekolah di Cakung Payangan Bekasi. Penelitian ini menggunakan desain cross-sectional dengan jumlah subjek 80 orang siswa yang diambil secara acak. Hasil analisis menunjukkan terdapat hubungan yang signifikan antara konsumsi fast food dengan gizi lebih $(\mathrm{p}=0,013$, CI $95 \%=1,420-10,977)$ dan hasil yang signifikan antara aktivitas fisik dengan gizi lebih $(\mathrm{p}=0,027, \mathrm{CI} 95 \%=$ 1.023 - 74.825). Konsumsi fast food dan aktivitas fisik memiliki hubungan yang signifikan dengan kejadian gizi lebih pada siswa usia sekolah.
\end{abstract}

Kata Kunci: Aktivitas fisik, anak usia sekolah, konsumsi fast food, status gizi lebih. 
Received : September, 20, 2020 Accepted : November, 5, 2020 Published: November, 30, 2020

\section{Introduction}

School-age is also called the period of intellectual development on children because in that phase, children tend to show their desire. Also, they are open to earn knowledge and experience. At this age, children have high curiosity and have a realistic nature. ${ }^{1}$ The middle and late childhood at the age of 6-12 years is a developmental period and included in the school-age group. ${ }^{2}$ One of the nutritional problems among school-age children is overweight and obesity. Obesity in children increases blood pressure, which later increases the risk of cardiovascular diseases in adults. ${ }^{3}$ Overweight and obesity will not only affect their physical health and become a risk factor of degenerative diseases but also affect their mental health. ${ }^{4}$ Nowadays, almost all school-age children like to consume fast-food and practicing a sedentary lifestyle, thus are at risk for overnutrition.

The National Centre for Health Statistics data in 2011-2014 showed the prevalence of obesity increased significantly among children who were 2-19 years old. During 2011-2012, $16.9 \%$ of 2-19-year-old children in the United States were obese; this number increased to $17.2 \%$ in 2013-2014..$^{5}$ According to research conducted by Wijnhoven et al., in six countries in Europe, $18-29 \%$ of children were categorized as overweight, and as many as $5-14 \%$ of children were obese. $^{6}$ The Basic Health Survey (RISKESDAS) in 2013 showed the national prevalence of overweight in 2-19-year-old children was still high, that is $10.8 \%$, and obesity was as high as $8.8 \%$. In West Java, the prevalence of overnutrition in adolescents aged 6-18 years was 8.8\% in $2013 .{ }^{7}$ Overnutrition among school-age children can be caused by several factors, including the interaction of nutrient intake, fast-food consumption, sedentary lifestyle, genetic, screen time, and other longterm factors. ${ }^{8}$

According to the World Health Organization (WHO), from 1999 to 2008, fast-food consumption increased from 26.61 to 32.76 per capita. The highest increases were in Canada (16.6), Australia (14.7), Ireland (12.3), and New Zealand (10.1), while the lowest increases were in Italy (1.5), Greece (1.9), The Netherlands $(1,8)$, and Belgium $(2,1) .{ }^{9}$ The frequency of fast-food consumption has increased in Indonesia. As shown by RISKESDAS 2013, the national proportion of people aged $\geq 9$ years who consume fast-food $>$ once a day was $40.7 \%$. Five provinces with the highest prevalence above the national average were Central Java (60.3\%), DI Yogyakarta (50.7\%), West Java (50.1\%), East Java (49.5\%), and Banten (48,8\%). The excessive consumption of fastfood is closely related to overnutrition (overweight and obesity). ${ }^{7}$ Fast food is easily prepared , and processed food served as a quick meal. Fast food contains high energy, high fat, and high sodium but low in fiber. Various food categorized as fast food includes potato fries, chicken fried with flour, hamburger, various soft drinks, pizza, doughnut, etc. ${ }^{10}$ 
Physical activity is also one of the factors associated with the incidence of overnutrition. Previously, children games require physical activities that demand them to run, jump, or do other movements, but now those games were replaced by sedentary games such as electronic games, computer, or television, which can be played sitting in front of the monitor with no additional movement required thus children's physical activity is relatively mild. ${ }^{11}$ Regarding energy balance, a deficit in energy expenditure is affected by low physical activity. If it occurs for a more extended period, it will worsen their nutritional status. This study aims to determine the correlation between fast-food consumption and physical activity with the incidence of overweight among school-age children in Cakung Payangan Bekasi.

\section{Method}

This is an observational study using a cross-sectional design. This study was conducted from January to May 2018. The target population in this study were 292 students at SD Strada Cakung Payangan, Bekasi. The study participants were recruited using simple random sampling method.Total number of participants was calculated using the Lemeshow formula.

$$
\begin{aligned}
\mathrm{n} & =\frac{\mathrm{z}^{2} 1-\alpha / 2 \mathrm{P}(1-\mathrm{P}) \mathrm{N}}{\mathrm{d}^{2}(\mathrm{~N}-1)+\mathrm{z}^{2} 1-\alpha / 2 \mathrm{P}(1-\mathrm{P})} \\
& =\frac{(1,96)^{2} \times 0,39 \times(1-0,39) \times 292}{(0,1)^{2} \times(292-1)+(1,96)^{2} \times 0,39 \times(1-0,39)} \\
& =\quad 77 \text { students }
\end{aligned}
$$

Keterangan:

$\mathrm{z}^{2}=$ Standard normal variate corresponding to the level of significance $95 \%(1,96)$

$\mathrm{P}=$ Population proportion derived from previous study $39 \%(0,39)$

$\mathrm{n}=$ Sample size

$\mathrm{N}=$ Population size

$\mathrm{d}=$ Degree of accuracy $=0,1(10 \%)$

According to the calculation, the minimum sample was 77 Participants In total, we examined 80 students as study participants.Participants were selected from grade 4 and 5 students.

The data collected in this study were fast-food consumption and physical activity, while participants' characteristics data consists of age and gender. Fast-food consumption and physical activity were measured using a food frequency questionnaire (FFQ) by looking at the consumption within the last month. Fast-food consumption is categorized as frequent if students consume fastfood $\geq 2 \mathrm{x} /$ week and are categorized as not frequent if they consume fast-food $\leq 2 \mathrm{x} /$ week. $^{12}$ Physical activity was measured using the Physical Activity Level (PAL) questionnaire. Mild physical 
activity is defined by a mean of 1,40-1,69 while moderate physical activity is defined by a mean of $1,70-1,99 .^{13}$

The assessment of students' nutrition status was calculated using anthropometry measurement and then assessed using Body Mass Index (BMI)-for-Age. The body weight data was measured using a digital weighing scale from The Omron brand with a maximum capacity of 150 $\mathrm{kg} 0.1 \mathrm{~kg}$ accuracy. The height was measured using a calibrated stature meter (microtoise) from GEA brand with $200 \mathrm{~cm}$ maximum height and $0.1 \mathrm{~cm}$ accuracy. The students' nutrition status was assessed using BMI-for-age referring to WHO 2005 standard, with the following cut-offs: obesity>2 SD, overweight $1 \mathrm{SD}$ to $2 \mathrm{SD}$ and normal $-2 \mathrm{SD}$ to $1 \mathrm{SD}$. In this study, BMI is split into two categories, normal and overweight. Normal is defined by a BMI of -2SD to 1 SD , while overweight is defined by BMI $>1$ SD.

The data analyzed using both univariate and bivariate statistical analyses using the Chisquare test. The univariate analysis was performed to describe participants' characteristics, while bivariate analysis - in this study, the Chi-square test, was performed to determine any existing association. The research ethics committee has approved the current study with the approval number: B/1050/VI/2017/KEPK. Before the commencement of the study, the researcher gave the necessary explanation to the participants and participants' guardians that this study aims to fulfill scientific needs. Then the written consents for participation were obtained from the guardian using informed consent.

\section{Results}

Table 1 shows the univariate analysis results based on gender, age, total/level consumption of fast-food, and sedentary activity distributions. 80 participants were involved in this study.

Table 1. Univariate Analysis

\begin{tabular}{|c|c|c|}
\hline Variables & $\mathbf{n}$ & $\%$ \\
\hline \multicolumn{3}{|l|}{ Nutritional Status } \\
\hline Overweight & 41 & 51.25 \\
\hline Normal & 39 & 48.75 \\
\hline \multicolumn{3}{|l|}{ Gender } \\
\hline Male & 35 & 43.8 \\
\hline Female & 45 & 56.2 \\
\hline \multicolumn{3}{|l|}{ Age (Years) } \\
\hline $8-9$ & 60 & 75 \\
\hline $10-11$ & 20 & 25 \\
\hline \multicolumn{3}{|l|}{ Total Fast-Food Consumption } \\
\hline Frequent & 54 & 67.5 \\
\hline Not frequent & 26 & 32.5 \\
\hline \multicolumn{3}{|l|}{ Physical activity } \\
\hline Mild & 70 & 87.5 \\
\hline Moderate & 10 & 12.5 \\
\hline
\end{tabular}


Based on Table 1, the gender variable was divided into two groups; male and female. It was shown that the participants were mainly female (56.2\%) compared to male (43.8\%) based on participants' gender distribution. Meanwhile, based on participants' distribution recap, participants aged $\leq$ ten years $(60 \%)$ were more than those aged $>10$ years $(25 \%)$.

Based on variable distributions, the fast-food consumption level in a week were divided into two groups; frequent $(\geq 2 \mathrm{x} /$ weeks $)$ and not frequent $(\leq 2 \mathrm{x} /$ weeks). The level of fast-food consumption was shown based on a median of the seven types of fast-food that the participants usually consume. From 80 participants, the median value was taken to determine the level of fastfood consumption. It was found that the level of fast-food consumption from frequent groups $(67.5 \%)$ was more than the level of fast-food consumption from the not frequent group (32.5\%).

Physical activity is categorized into mild and moderate activity. Mild physical activities include watching television, playing with a gadget, playing video games, and other activities that are usually done while sitting or lying down. While moderate physical activities include doing laundry, playing football, joining a sports club, helping parents, and other activities that require children to move a lot. ${ }^{14}$ Based on the physical activity variable distribution during school days for mild category $(87.5 \%)$ was more than the moderate $(12.5 \%)$. The detailed results of the bivariate analysis are shown in table 2.

Table 2. Bivariate Analysis

\begin{tabular}{|c|c|c|c|c|c|c|c|c|}
\hline \multirow[t]{2}{*}{ Variables } & \multicolumn{2}{|c|}{ Normal } & \multicolumn{2}{|c|}{ Overweight } & \multirow{2}{*}{ p-value } & \multirow{2}{*}{ OR } & \multicolumn{2}{|c|}{ CI $95 \%$} \\
\hline & $\mathbf{N}$ & $\%$ & n & $\%$ & & & Lower & Upper \\
\hline \multicolumn{9}{|c|}{ Fast-food Consumption Habits } \\
\hline Frequent & 7 & 26.9 & 19 & 73.1 & \multirow[t]{2}{*}{$0.013 *$} & \multirow[t]{2}{*}{3.95} & \multirow[t]{2}{*}{1.420} & \multirow[t]{2}{*}{10.977} \\
\hline Not Frequent & 32 & 59.3 & 22 & 40.7 & & & & \\
\hline \multicolumn{9}{|l|}{ Physical Activity } \\
\hline Mild & 32 & 44.4 & 40 & 55.5 & $0.027^{*}$ & 8.75 & 1.023 & 74.835 \\
\hline Moderate & 7 & 87.5 & 1 & 12.5 & & & & \\
\hline
\end{tabular}

*P-value $>0.005$

Based on the analysis results shown in table 2, the association between fast-food consumption habits with the overweight occurrence, it was found that the proportion of students with frequent fast-food consumption and having overweight was $73.1 \%$. Meanwhile, the proportion of students without frequent fast-food consumption while having normal body weight was $59.3 \%$. Statistically significant results were observed on the relationship between fast-food consumption habits and the occurrence of overnutrition with a p-value of less than 0,05 ; the value of 0,013 was obtained.

Based on the table.2, participants who had mild physical activity category with overweight were 40 participants $(55.5 \%)$. The statistical analysis gave a p-value of 0,027 . The p-value indicated that there was a significant association between physical activity and overweight. To 
conclude, there was a significant association between physical activity and nutrition status among elementary school children.

\section{Discussion}

This study shows that fast-food consumption and physical activity have a significant association with overweight occurrence among school-age children. Fast-food is one of the children's favorite food and consumed by a lot of children. Apart from the tastiness, these foods also have a quick preparation time and are considered to increase the social pride of people who consume it. Fast-food has limitations in nutrition content, but the World Health Organization (WHO) states that the increased fast-food consumption is a concerning problem. Problems related to nutrition increase in people whose families go out looking for fast-food because they do not have time to prepare a home-cooked meal at home. ${ }^{15}$

Moreover, growing evidence has explained how fast-food consumption is related to overweight occurrence. A research conducted in Jakarta stated that there was a correlation between energy-dense food (fast-food and soft drinks) consumption and obesity among elementary school students. ${ }^{16}$ Another research conducted in Manado showed a significant relationship between fastfood consumption and the obesity occurrence in elementary school children. ${ }^{17}$ Therefore, fast-food consumption leads to obesity occurrence among children and should be a concern for parents. Parents should limit fast-food and calorie-dense foods and drinks consumption on their child. Also, parents should educate their children to have a healthy lifestyle and familiarize kids with regular exercise. $^{17}$

A research conducted in Brebes showed that there was a significant relationship between fast-food consumption and the obesity occurrence among elementary school students $(p=0.036) .{ }^{16}$ Another previous study also showed that elementary school students who consume fast-food $>3$ times/week have a 2.8 times greater risk of becoming overweight than those who consume fastfood less frequently. ${ }^{18}$ Fast-food consumption and the lack of regular exercise will affect weight gain within a few weeks. ${ }^{18}$

Nutrition status is influenced by daily food consumption and eating habits. ${ }^{19}$ Fast-food is known as energy-dense, high fat, and low fiber foods, so it is associated with body fat deposition leading to excess weight gain if there is an imbalance between energy intake and expenditure. ${ }^{20}$ Junaidi, in his study, explained that fast-food consumption habits have a significant relationship $(p=0.024)$ with obesity among elementary school children in Banda Aceh. ${ }^{10}$ Hence, the frequent consumption of fast-food in children lead to a rapid increase in nutrition status then causes obesity. ${ }^{10}$ High energy intake in children who consume a vast amount of fast foods and soft drinks that exceed their daily energy requirement without -adequate physical activity may cause obesity because they have excessive energy intake. ${ }^{17}$ A report by French (2001) explained that $75 \%$ of 
adolescents dined in at a fast-food restaurant for several weeks. Male and female adolescents who visited fast-food restaurants $>3$ times a week had a higher energy intake as much of $40 \%$ and $37 \%$, respectively, compared to those who did not dine in at a fast-food restaurant. ${ }^{21}$

The results of subsequent studies reported that fast-food consumption was high among children and tended to increase as they grow into adults. ${ }^{22}$ Comparing to those who rarely consume fast-food, children who often and very often consume fast-food have a higher BMI. ${ }^{22}$ Poti et al. in their study, found that half of the American children are very fond of consuming fast-food. There are $39.5 \%$ of kids with low consumption of fast-food ( $\leq 30 \%$ energy comes from fast-food), and $10.5 \%$ have a high fast-food consumption( $>30 \%$ energy comes from fast-food). Children who frequently consume fast-food have 2.21 times higher risk of being obese compared to the children who consume fast-food less frequently; 1.51 times the risk of being obese. ${ }^{23}$

Low physical activity among students may be related to dramatic changes in children's lifestyles, such as too much playing games on cell phones rather than doing physically active games like playing ball. Also, the use of the motorized vehicle for long-distance mobility nowadays replace walking, running, or cycling. ${ }^{24}$ Regarding physical activity, researchers found that most of the overweight students did mild to low physical activity (Table 2). Children who did mild physical activity have 2,5 times higher risk of being obese compared to children who did the moderate physical activity. A case-control study in Bangladesh found a 60 percent increased risk of obesity for children who do not exercise regularly at home. ${ }^{25}$

Furthermore, a research conducted by Ermona found that there was a significant relation between mild physical activity and students' nutrition status in Surabaya (0.024). ${ }^{26}$ The result of this study is similar to the study conducted in Manado where a significant relationship between physical activity and obesity was observed among elementary school children in Manado. From this study, $85.3 \%$ of the elementary school students are obese, while the other $14.7 \%$ were not. ${ }^{11}$ Another study also explained that there was a significant relationship between children with mild physical activity and consumption of fried foods with overweight occurrence. Mild physical activity and consumption of fried foods increase the risk of being overweight. Obesity occurs due to an imbalance between food consumption and energy expenditure for a prolonged time. ${ }^{27}$

The results of this study are also in line with a research conducted in Bantul, which reported a significant relation between physical activity and the incidence of obesity among children $(\mathrm{p}=0.009){ }^{28}$ Similarly, research conducted in Serang found a significant relation between mild physical activity and obesity among adolescents. With $\mathrm{p}=0.000$, mild physical activity increased the risk of obesity by 4.63 times in adolescents. ${ }^{29}$ Low physical activity promotes a positive energy balance, then the excess of energy is stored as body fat. ${ }^{30}$ Lifestyle changes also affect dietary habits that mainly consist of calorie-dense and high fat and cholesterol foods, which, unfortunately, is not followed by physical activity will lead to overweight problems. Dietary habits 
that high in calories, fat, and cholesterol should be balanced with physical activity to compensate for the nutrition intake. Physical activity in children will affect their BMI; hopefully, it can reduce the risk of having overnutrition problems. ${ }^{31}$ The recommended physical activity in children with the general population is $\geq 60$ minutes of daily physical activity, including aerobics, muscle, and bone-strengthening activities. Aerobics should be done frequently, while muscle and bonestrengthening activities should be done at least three times a week. ${ }^{32}$ Physical activities that can be done include daily walking, exercise, running, and other outdoor activities.

These findings are in line with a research conducted in the UK that reported a significant association between physical activity and the incidence of overnutrition with $\mathrm{p}=0,000(\mathrm{p}<0,05) .{ }^{33}$ This study is also similar to a research conducted by Simatupang, which found a significant relationship between physical activity and the incidence of overnutrition with a p-value of $<0,05 .{ }^{34}$ According to the level of physical activity, doing physical activity ranging from moderate to vigorous can reduce the occurrence of obesity. Most of the children have mild physical activity; this is due to technological advances and daily routine. ${ }^{35}$ Advances in technology such as television, computer, and the internet also play a role in the sedentary lifestyle development among children. Children prefer spending most of their time doing passive activities, such as playing video games, online games, surfing the internet, and watching television, which children spend about 3 hours daily watching television broadcast. These passive activities do not require a lot of energy. As a result, they are also at risk of developing obesity. ${ }^{36}$

\section{Conclusion}

In summary, from the data of the present study, fast-food consumption and mild physical activity have a significant relationship on overweight occurrence among school-age students. Frequent consumption of fast-food and mild physical activity become problems currently faced by school-age children. Hence, seeing the significant relation between fast-food consumption and mild physical activity highlights the importance of having an education on the principles of a balanced diet for school-age children. Furthermore, bodyweight monitoring can be conducted simultaneously with the Health Encouragement Activities at school (Usaha Kesehatan Sekolah) as monitoring and prevention efforts to combat overweight. Nutrition intervention for overweight school-age children should also take the environment into account, both at school and at home, especially those related to diet. Providing nutritional education about healthy and balanced diet for school-age children is a way for researchers to improve the eating habits of school-age children. Furthermore, an adequate physical activity can be achieved by doing various outdoor activities and exercise. Students are also advised to join extracurricular activities in sports in addition to their existing exercise included in their weekly curriculum. 


\section{Acknowledgment}

We would like to express our gratitude to the Strada Cakung Payangan Primary School, Bekasi, for the cooperation. Equally, we are grateful to all contributing parties, especially the lecturers and research team.

\section{Funding}

There is no funding for this research, and the funds used are the author's personal funds.

\section{Conflict of Interest}

There is no conflict of interest in this study.

\section{Reference}

1. Purnamawati I. Hubungan permainan video games dengan pola makan dan status gizi anak usia sekolah di sd muhammadiyah condong catur, sleman. Skripsi, Univ Muhammadiyah Yogyakarta. 2014.

2. Santrock JW. Educational Psychology. 5th ed. Newyork: McGrawHill Companies; 2011.

3. Feeley AB, Norris SA. Added sugar and dietary sodium intake from purchased fast food, confectionery, sweetened beverages and snacks among Sowetan adolescents. South African J Child Heal. 2014;8(3):88-91.

4. Hasdianah, Siyoto HS, Yuly P. Gizi Pemantapan Gizi, Diet dan Obesitas. Yogyakarta: Nuha Medika; 2013.

5. Hales CM, Carroll MD, Fryar CD, Ogden SL. Prevalence of Obesity Among Adults and Youth: United States, 2015-2016. NCHS Data Brief. 2017;(288):1-8.

6. Wijnhoven TMA, van Raaij JMA, Spinelli A, Starc G, Hassapidou M, Spiroski I, et al. WHO European Childhood Obesity Surveillance Initiative: body mass index and level of overweight among 6-9-year-old children from school year 2007/2008 to school year 2009/2010. BMC Public Health. 2014;14(806).

7. Kemenkes RI. Riset Kesehatan Dasar 2013. Kementrian Kesehatan Republik Indonesia. 2013.

8. Boone JE, Gordon-Larsen P, Adair LS, Popkin BM. Screen time and physical activity during adolescence: longitudinal effects on obesity in young adulthood. Int $\mathrm{J}$ Behav Nutr Phys Act. 2007;4(26).

9. Vogli R De, Kouvonen A, Gimeno D. The influence of market deregulation on fast food consumption and body mass index: a cross-national time series analysis. Bulletin World 
Health Organization. 2014;92-9.

10. Junaidi, Noviyanda. Kebiasaan Konsumsi Fast Food Terhadap Obesitas pada Anak Sekolah Dasar Banda Aceh. AcTion : Aceh Nutrition Journal. 2016;1(2):78-82.

11. lolita Danari A, Mayulu N, Onibala F. Hubungan Aktivitas Fisik dengan Kejadian Obesitas pada Anak SD di Kota Manado. e-journal keperawatan. 2013;1(1):1-4.

12. Khomsan A. Solusi Makanan Sehat. Jakarta: PT Raja Grafindo Persada; 2006.

13. Food and Agriculture Organization of the United Nations. Human energy requirements: Energy Requirement of Adults [Internet]. Report of a Joint FAO/WHO/UNU Expert Consultation. 2004. Available from: http://www.fao.org/3/y5686e/y5686e07.htm

14. Musadat A. Analisis faktor-faktor yang mempengaruhi kegemukan pada anak usia 6-14 tahun di Sumatera Selatan [Thesis]. Institut Pertanian Bogor; 2010.

15. WHO. Redifining Obesity and Its Treatment. 2000; Available from: http://www.wpro.who.int/nutrition/documents/docs/Redefiningobesity.pdf

16. Septiani R, Raharjo BB. Pola Konsumsi Fast Food, Aktivitas Fisik dan Faktor Keturunan Terhadap Kejadian Obesitas (Studi Kasus pada Siswa SD Negeri 01 Tonjong Kecamatan Tonjong Kabupaten Brebes). Public Health Perspective Journal. 2017;2(3):262-9.

17. Damopolii W, Mayulu N, Masi G. Hubungan Konsumsi Fastfood dengan Kejadian Obesitas pada Anak SD di Kota Manado. e-journal keperawatan. 2013;1(1).

18. Badjeber F, Kapantouw NH, Punuh M. Konsumsi Fast Food sebagai Faktor Risiko Terjadinya Gizi Lebih pada Siswa SD Negeri 11 Manado. KESMAS. 2012;1(1):11-4.

19. Hanum TSL, Dewi AP, Erwin. Hubungan Antara Pengetahuan dan Kebiasaan Mengkonsmsi Fast Food dengan Status Gizi pada Remaja. Jurnal Online Mahasiswa Universitas Riau. 2015;2(1).

20. Sahoo K, Sahoo B, Choudhury AK, Sofi NY, Kumar R, Bhadoria AS. Childhood obesity: Causes and Consequences. Journal of Family Medicine Primary Care. 2015;4(2):187-92.

21. French SA, Story M, Neumark-Sztainer D, Fulkerson JA, Hannan P. Fast food restaurant use among adolescents: Associations with nutrient intake, food choices and behavioral and psychosocial variables. International Journal of Obesity. 2001;25(12):1823-33.

22. Braithwaite I, Stewart AW, Hancox RJ, Beasley R, Murphy R, Mitchell EA. Fast-food consumption and body mass index in children and adolescents: An international crosssectional study. BMJ Open. 2014;4(12):1-9.

23. Poti JM, Duffey KJ, Popkin BM. The association of fast food consumption with poor dietary outcomes and obesity among children: Is it the fast food or the remainder of the diet? American Journal of Clinical Nutrition. 2014;99(1):162-71.

24. Sağlam H, Tarim O. Prevalence and Correlates of Obesity in Schoolchildren from the City 
of Bursa, Turkey. Journal of Clinical Research in Pediatric Endocrinology. 2008;1(2):80-8.

25. Bhuiyan MU, Zaman S, Ahmed T. Risk factors associated with overweight and obesity among urban school children and adolescents in Bangladesh: a case-control study. BMC Perdiatrics. 2013;13(72).

26. Ermona NDN, Wirjatmadi B. Hubungan Aktivitas Fisik Dan Asupan Gizi Dengan Status Gizi Lebih Pada Anak Usia Sekolah Dasar Di Sdn Ketabang 1 Kota Surabaya Tahun 201. Amerta Nutrition. 2018;2(1):97-105.

27. Putri VR, Angkasa D, Nuzrina R. Konsumsi Fast Food, Soft Drink, Aktivitas Fisik, dan Kejadian Overweight Siswa Sekolah Dasar di Jakarta. Indonesian Journal of Human Nutrition. 2017;4(1):48-58.

28. Zamzani M, Hadi H, Astiti D. Aktivitas Fisik Berhubungan dengan Kejadian Obesitas pada Anak Sekolah Dasar. Jurnal Gizi dan Dietetik Indonesia. 2016;4(3):123-8.

29. Pramono A, Sulchan M. Kontribusi Makanan Jajan dan Aktivitas Fisik Terhadap Kejadian Obesitas pada Remaja di Kota Semarang. Gizi Indonesia. 2014;37(2):129-36.

30. Stubbs RJ, Hughes DA, Johnstone AM, Horgan GW, King N, Blundell JE. A decrease in physical activity affects appetite, energy, and nutrient balance in lean men feeding ad libitum. Am J Clin Nutr. 2004;79(1):62-9.

31. Salbe AD, Weyer C, Harper I, Lindsay RS, Ravussin E, Tataranni PA. Relation between physical activity and obesity. The American Journal of Clinical Nutritr. 2003;78(1):193-4.

32. Adolfsson P, Riddell MC, Taplin CE, Davis EA, Fournier PA, Annan F, et al. ISPAD Clinical Practice Consensus Guidelines 2018: Exercise in Children and Adolescents with Diabetes. Pediatric Diabetes. 2018;19(27):205-26.

33. Inggrid C. Hubungan Antara Aktivitas Fisik dengan Status Gizi Pelajar SMP Frater Don Bosco Manado. 2012.

34. Simatupang MR. Pengaruh Pola Konsumsi, Aktivitas 9. Fisik dan Keturunan terhadap Kejadian Obesitas pada Siswa Sekolah Dasar Swasta di Kecamatan Medan Baru Kota Medan [Thesis]. Universitas Sumatera Utara. 2008.

35. Almatsier S. Prinsip Dasar Ilmu Gizi. Jakarta: PT Gramedia Pustaka Utama; 2009.

36. Iswati N, Desyarti N, Nurlaila. Pola Makan dan Pola Aktifitas pada Anak Obesitas di SD Islam Al-Hikmah Selokerto Kecamatan Sempor. Jurnal Ilmiah Kesehatan Keperawatan. 2018;14(3). 